\title{
ASSESSING PUBLIC PERCEPTION FOR ILLUMINATION OF BUILDING IN KAYUTANGAN STREET, MALANG, INDONESIA
}

\author{
Baskoro Azis $^{1^{*}}$, Herry Santosa ${ }^{2}$, Jenny Ernawati ${ }^{3}$ \\ ${ }^{1}$ Magister Student of Architecture, Brawijaya University, Jl. MT Haryono No. 167 Malang, Indonesia \\ ${ }^{2,3}$ Department of Architecture, Brawijaya University, Jl. MT Haryono No. 167 Malang, Indonesia \\ *Corresponding author; email: baskoro.azis@gmail.com
}

\begin{abstract}
Malang is well-known for colonial buildings. Visual quality of building in the Kayutangan corridor makes it an icon of Malang City. Assessment of visual quality is affected by daytime and nighttime conditions. Day and night lighting are factors that influenced the visual quality assessment of buildings. This study meant to assess the visual quality of buildings in the kayutangan corridor which has a history and aspects that influence by society during the day and night. This study used a descriptive quantitative method explaining public perception about the visual quality of buildings in Kayutangan street corridors during the day and night. Semantic Differential Scale was the instrument to describe the respondents' perceptions. From the result showed that visual quality of four of 10 buildings have a low scores and there are six variables that have the most influence on daylight and eight variables at night on buildings in the Kayutangan corridor.
\end{abstract}

Keywords: Visual quality; building; lighting; SD; perception.

\section{INTRODUCTION}

Malang is a city that has many historical in the form of colonial buildings. The existence of historical buildings in Indonesia often does not receive particular attention. The building conditions tend to be very concerned, both physically and functionally. Kayutangan area was once the center of trade and the main road in the past. However, now, its glory and history gradually begin to fade. The building conditions are diverted visually by the urban development to be able to compete with other regions. It includes the architectural style diversion without concerning the context, making the elements of the buildings invisible. The existence of buildings with distinctive colonial architecture provides features that can attract public attention in the area.

Meanwhile, Sachari (2007) stated that architecture is the primary visual element serving as the basis of an urban image through which the design activities of a city as the most visually real actualization can represent the era. That is, the existence of a city is inseparable from the history and surrounding buildings. Therefore, the colonial buildings are still maintained and used as a Heritage Track by the government and academics.

The corridor of Kayutangan street, including the shape and row of buildings were wholly constructed and influenced by the history, function, and architecture of buildings, was easily remembered by the community. Moreover, one of the factors influencing the community judgment is the lighting factor. Human eyesight used to captures visual beauty leads perception and information of an object through reflected light to assess visual quality, especially in historical buildings. The abandonment and changes in the buildings can affect the facades of the buildings, automatically generating a negative impression or only benefiting some certain organizations that see it. The impression greatly depends on how individuals respond to these objects with their visual perception. In reality, most of the impression generated on a building object is determined by its visual perception. One of the reasons why visual perceptions are so important in interpreting our surroundings is that each of us perceives objects, but our perceptions of what is meant by an ideal situation are different. Thus, visual perceptions are highly important to be discussed for visual quality assessment.

Visual quality is an assessment emerging from perceptions, and human feel when they see something or related to visual senses. Visualization of visible objects is the visual quality owned by the object connected with the perception assessment that appears when interpreted. Visual imaginary of an area in a city can give an impression or perception to the observer. The impression of the area is influenced by three aspects, namely identity, Basic Form, and meaning (Lynch, 1969). Visual aesthetic values and environmental forms will lead observers to shape impressions or perceptions or feel with their visual senses of the area (Lynch, 1969). Many studies have discussed the visual quality of Malang City, particularly on the corridor of Kayutangan street which has a lot of tangible and intangible history. This location is being debated and studied by many parties such as 
academics, historians, the government, communities concerned about the Kayutangan historical area. However, no researcher has conducted visual quality research with daylight and night light the corridor of Kayutangan street. An observer's visual perception of a street area or corridor is also influenced by its supporting element, namely lighting. The user reaction to the building in an environment was stated by Boyce (1998) in IEA, that maximum natural lighting was highly required to meet the basic need of human, namely the obvious need to see clearly in rooms and to experience the environmental stimulation from the lighting effects.

Visual quality arising due to lighting effects can trigger someone to explore others' memories to give opinions through each's experience. Differently, Manurung (2008) explained that the lighting factor during the day could generate safe and attractive impressions to buildings. On the other effect, the lighting factor at night gives negative impressions dominated by visual perceptions that the buildings look dark, fuzzy, gloomy, and boring. Visual quality can be interesting to be examined more deeply by comparing community perceptions through the lighting factor. This is because the lighting factor of buildings during the day and night gets a different response of visual quality and perceptions generated by the community.

Other research explained that lighting at night is affected by artificial lighting should be able to improve the visual quality of a building, particularly its visual characteristics; poorly-built artificial lighting will decrease visual quality of the building (Manurung, 2015). There is a contrast between the quality of lighting during the day and night. The public associated lighting quality during the night with negative adjectives. Hence, there is a need to perform a study discussing visual quality during the day and that during the night.

Some researchers focused on visual quality in buildings during the day. (Askari and Dola, 2009; Perovic and Folic, 2012; Liu et al., 2015; Mahmoudi and Ahmad, 2015; Jennath and Nidhish, 2016) On the other hand, other researchers conducted previous studies discussing visual quality in buildings during the night. (Anggriani, 2007; Gokhale, 2013; Rankel, 2014; Hafiz, 2015) Some literature review studies are contrasting visual quality in buildings during the day and night.(Cafuta, 2014; Mahmoudi and Ahmad, 2015; Widiantoro et al., 2015; Robert et al., 2015) Kayutangan has become the setting of several previous studies discussing visual (Karisztia et al., 2008; Fauziah et al., 2012; Santosa et al., 2013, 2014). However, they have yet to discuss utilization of artificial lighting in buildings located in Kayutangan and how much influence the lighting has towards the visual quality of the buildings during the day and night.

Analyzing the influence of visual quality and lighting towards visual quality will give information on how much the impact of natural and artificial lighting has towards public space or buildings. Suitable lighting, from both natural and artificial sources, allows visitors to enjoy public space or architecture of a building optimally, and creates lasting positive impression and revisit intention.

\section{METHODOLOGY}

The study was a descriptive quantitative study describing the results of the respondent's field questionnaire data are represented in public perception about the visual quality of the buildings and influenced by the history, function, and architecture of buildings located in Kayutangan street corridor during the day and night.

The setting of the study was a street called Basuki Rahmat, Klojen, Malang. It is known as "Kayutangan." Various colonial buildings in the city are located in "Kayutangan" This area was selected as the setting of this study because it was history and there have been several debates about this location among historical experts, public figures and both public and private organizations. A total number of buildings in this street corridor is 29 buildings. These buildings are used as stores and office buildings currently.

The population is entire objects that have particular characteristics to observe. The sample is a smaller group that represents the population. There were two types of the population this study, buildings, and user or observer.

There are 31 buildings that influenced by the history, function, and architecture of buildings located along Kayutangan street corridor. 29 of them were colonial buildings. The sampling criteria were building that was built at least 50 years ago, has a specific contribution towards history, knowledge, education, religion, and culture contains cultural value and more importantly, remains intact.

Based on the criteria, ten buildings became the samples. These buildings remain intact, are used as either residential, office buildings or commercial buildings, are more than $100 \mathrm{~m}^{2}$ and not covered by any medium that prevents the observer from evaluating their visual quality. The samples were as follows:
1. AVIA Supermarket
2. Electric Company building
3. LIE Store
4. Rajabally
5. CIMB Niaga 


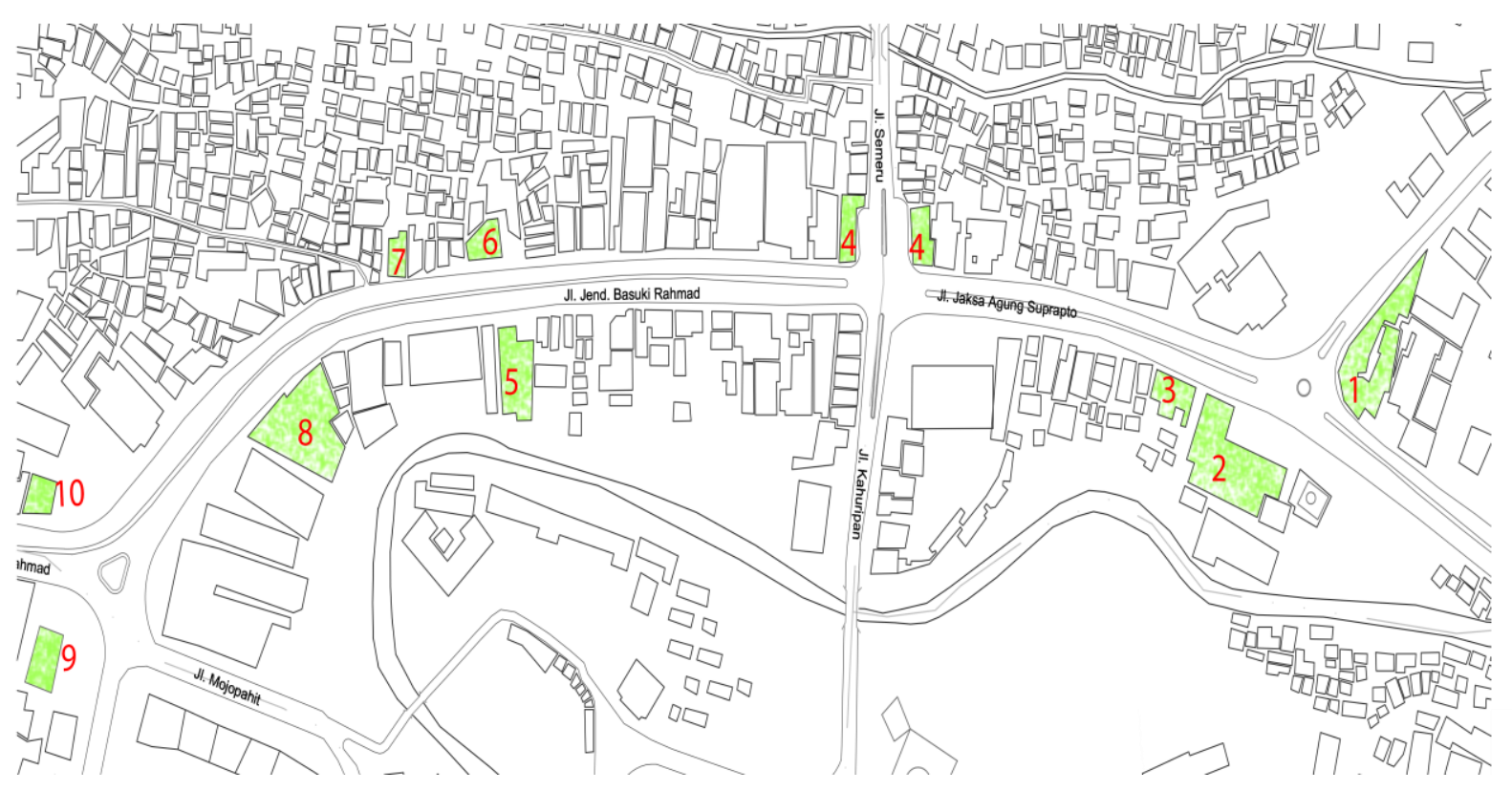

Fig. 1. Colonial Building Location, Kayutangan, Malang City

6. Optic Surya

7. Namsin House

8. Riang Store

9. Kayutangan Church

10. OEN Restaurant

Respondents participated in this research was individuals who live in Malang and carry out their activities along Kayutangan street corridor. They evaluated visual qualities of the buildings located in the street corridor during the day and night. The sampling technique was purposive sampling (nonprobability sampling technique).

This study consists of three groups used different sampling techniques that are road users, practitioners and academics. Road users used accidental sampling techniques. While academics and practitioners used purposive sampling technique. Total samples were 200 people, and they evaluated the visual quality of the buildings using the Semantic Differential Scale (SD).

In this study the population is unknown, so to determine the number of samples taken with the following formula.

$$
\mathrm{N}=0,25 \times\left(\frac{Z a / 2}{\varepsilon}\right)^{2}
$$

Where:

$N=$ number of sample

$\varepsilon=$ margin of error $(10 \%)$

$Z a / 2=$ values obtained from normal tables for confidence levels (level of research confidence $95 \%=1,96$ )

$\mathrm{N}=0,25 \times\left(\frac{1,96}{0,1}\right)^{2}=96,04=100$ respondents
These scores are used to discuss visual quality assessments during the day and night with the same respondents.

There were 14 variables in evaluating the visual quality of those buildings, which derived from previous research such as Santosa, Askari, Widiantoro, Karisztia and Fauziah discussed about Building Mass and Basic Form. Liu, Santosa, Manurung, Askari, Kamurahan, Fauziah, Jennath and Nidhish discussed about Color (Characteristis, Saturation, Brightness). Fauziah, Jennath, Askari and Manurung discussed about Texture. Other Research such as Nurmasari and Kamurahan discussed about design principles cohesiveness, balance, and function.

To measure community assessment variables, a semantic differential scale was developed. Based on previous research, 14 items have been chosen to ensure that they can give people an impression of buildings. Nine of 14 items were chosen to reflect people's assessment of form and aesthetic of the building. These were derived from previous research of the experience of University of Toyama conducted by Zhang et. al. (2010). The research explained that building have perception closed-open, cold-warm, dark-light, lonesome-lively, ugly-beautiful, not suitable-suitable, inartistic-artistic, shabby-excellent, and unpleasant-pleasant. Other research, Sanoff, (1991), Flynn (1973), and Manurung (2008) explained about faded-bright, firm-soft, common-interesting, and unsafe-safety. Another study, Ernawati and Moore (2014) also discussed about common-interesting, unpleasant-pleasant, and ugly-beautiful. 
Tabel 1. Variable Tables and Measurements of Semantic Differential

\begin{tabular}{cccccccccc}
\hline Variable (Aspect of Evaluation) & \multicolumn{7}{c}{ Measurement of the rating scale (negative-positive) } \\
\hline Building Mass & Closed & 1 & 2 & 3 & 4 & 5 & 6 & 7 & Open \\
Basic Form & Simple & 1 & 2 & 3 & 4 & 5 & 6 & 7 & Complicated \\
Color Characteristics & Cold & 1 & 2 & 3 & 4 & 5 & 6 & 7 & Warm \\
Saturation & Faded & 1 & 2 & 3 & 4 & 5 & 6 & 7 & Bright \\
Brightness & Dark & 1 & 2 & 3 & 4 & 5 & 6 & 7 & Light \\
Texture & Firm & 1 & 2 & 3 & 4 & 5 & 6 & 7 & Soft \\
Ambiance & Lonesome & 1 & 2 & 3 & 4 & 5 & 6 & 7 & Lively \\
Lighting Effect & Ugly & 1 & 2 & 3 & 4 & 5 & 6 & 7 & Beautiful \\
Harmony & Not suitable & 1 & 2 & 3 & 4 & 5 & 6 & 7 & Suitable \\
Attractiveness & Common & 1 & 2 & 3 & 4 & 5 & 6 & 7 & Interesting \\
Arts & Inartistic & 1 & 2 & 3 & 4 & 5 & 6 & 7 & artistic \\
Effect & Shabby & 1 & 2 & 3 & 4 & 5 & 6 & 7 & Excellent \\
Lighting security & Unsafe & 1 & 2 & 3 & 4 & 5 & 6 & 7 & Safety \\
Visual Comfort & Unpleasant & 1 & 2 & 3 & 4 & 5 & 6 & 7 & pleasant \\
\hline
\end{tabular}

(Source: Askari and Dola, 2009; Jennath and Nidhish, 2016; Liu et al., 2015; Mahmoudi and Ahmad, 2015; Perovic and Folic, 2012; Anggriani, 2007; Gokhale, 2013; Hafiz, 2015; Rankel, 2014; Cafuta, 2014; Mahmoudi and Ahmad, 2015; Widiantoro et al., 2015; Fauziah et al., 2012; Karisztia et al., 2008; Santosa et al., 2013- 2014; Zhang et al., 2010; Sanoff, 1991; Flynn, 1973; Ernawati and Moore, 2014; and Manurung, 2008)

For analyze the public perception, the visual quality of buildings in the Kayutangan corridor using the Semantic Differential Scale measurement. This measurement consists of seven scales using opposing words. Negative assessments are on the left side and the positive ones are on the right.

For efficiency and comparing visual quality of the buildings during the day and night, results of the questionnaire were formulated into tables using the web Google Form, Microsoft Excel, and SPSS. Google Form is used to get people assessment from the questionnaires that have been provided. After that, the data obtained is changed to Microsoft Excel format. The data that has been compiled will be analyzed using the SPSS program to get average people assessment and Multiple Linear Regression for get aspects that influence by society.

\section{RESULTS AND DISCUSSION}

This study evaluated the influence of lighting on the visual quality of buildings during the day and night. Based on 14 variables, the respondents decided on the visual quality of those buildings.

AVIA supermarket is one of the landmarks in Malang of which location is in Kayutangan street corridor. Another building located at the corridor of Kayutangan is State Electric Company office building called N.V. Algemeene Nederlandsch-Indische Electricities Maatschappij (ANIEM) which was built in 1930. This building is being across AVIA Building. SPSS was used to analyze average scores of AVIA supermarket and State Electric Company building visual quality during the day and night while Independent T-Test was used to analyze difference or similarity between AVIA supermarket and State Electric Company building visual quality scores during the day and night.

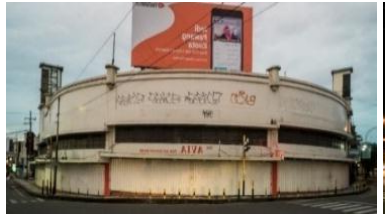

$1 \mathbf{a}$

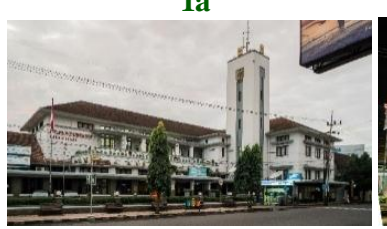

$2 \mathrm{a}$

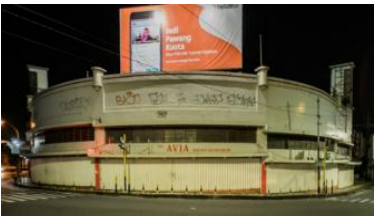

$1 \mathbf{b}$

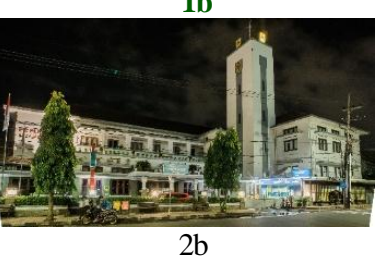

Fig. 2. 1a. Avia Supermarket - Day; 1b. Avia Supermarket - Night; 2a. Electric Company Building - Day; 2b. State Electric Company building - Night

The 100 respondents completed the measurement, and the results were compiled and tabulated (see Table 2). According to that table, the average value of each Avia building ranged from 4 to 5 with 4.64 points during the day and ranged from 5 to 6 with 5.12 points during the night. While in State Electric Company building, that ranged from 5 to 6 with 5.25 points during the day and 5.62 points during the night. These results indicate that the assessment during the day in Avia building has a good lighting assessment at night as well as the State Electric Company building.

LIE Store is the third building, and the oldest store in the corridor of Kayutangan and the fourth building is Rajabally Building. Rajabally has two building with same architectural form. 
Tabel 2. Average Score of "AVIA" (AVIA Supermarket) and State Electric Company Building

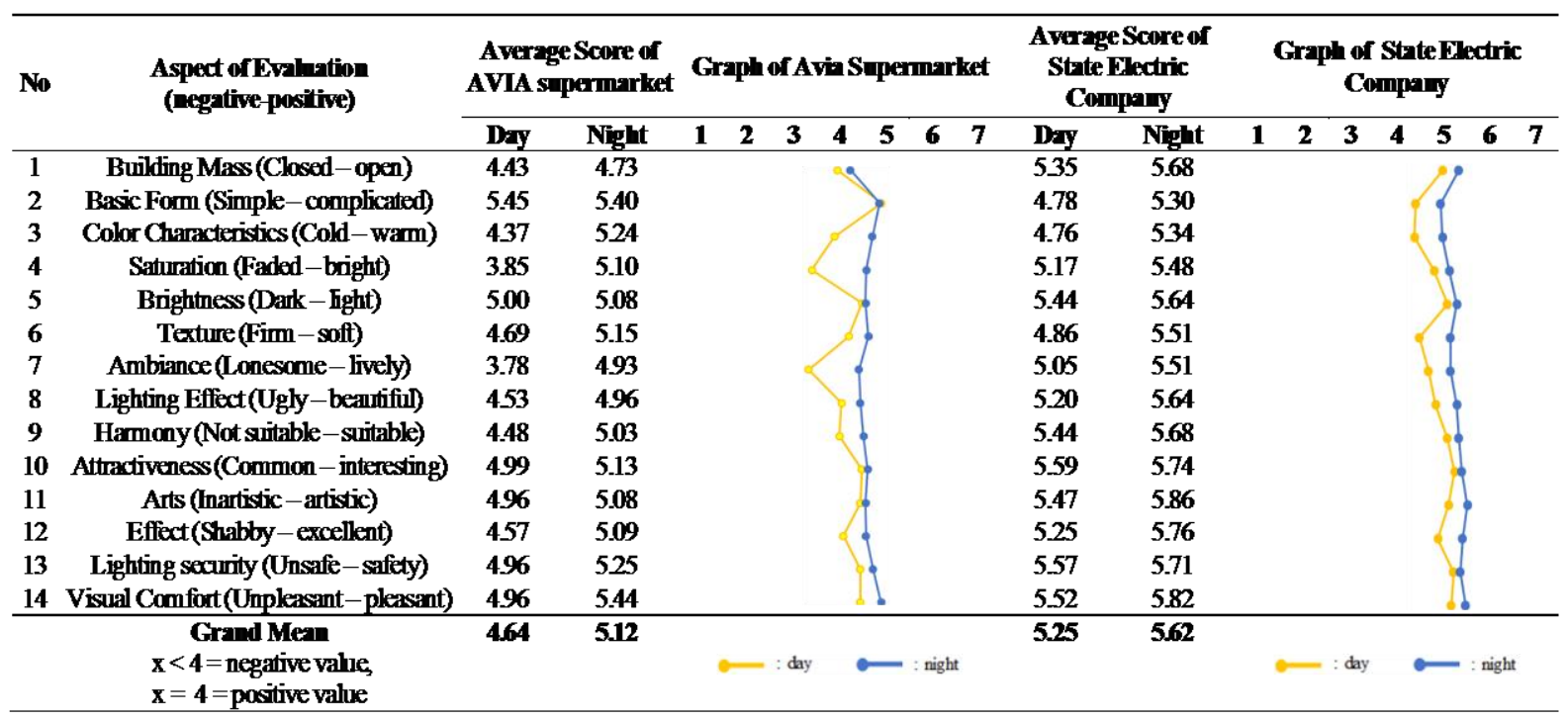

Notes: measurement scale of evaluation using a scale of 1 to 7 (from negative value to positive value)

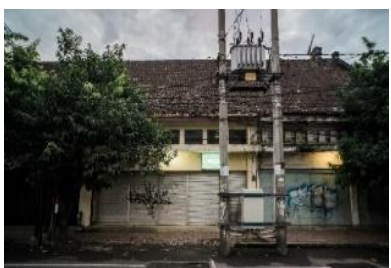

$3 a$

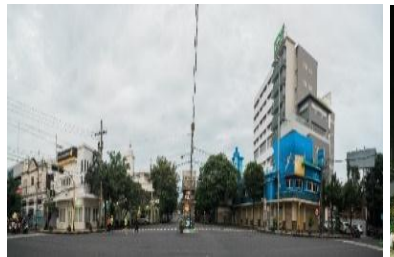

$4 \mathrm{a}$

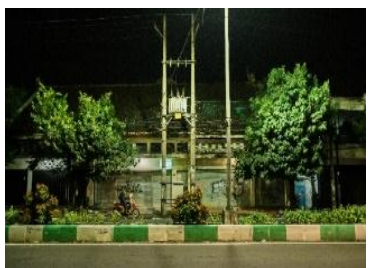

$3 \mathrm{~b}$

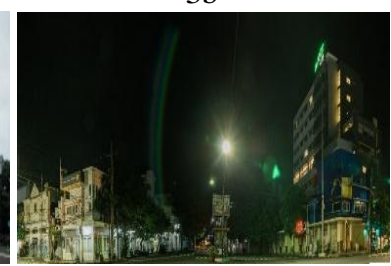

$4 b$

Fig. 3. 3a. LIE Store - Day; 3b. LIE Store - Night; 4a. Rajabally - Day; 4b. Rajabally - Night

The 100 respondents completed the measurement, and the results were compiled and tabulated (see Table 3). According to that table, the average value of each LIE Store building ranged from 3 to 4 with 3.85 points during the day and ranged from 3 to 4 with 3.50 points during the night. While in State Electric Company building, that ranged from 5 to 6 with 5.05 points during the day and ranged from 4 to 5 with 4.54 points during the night. These results indicate that the assessment during the day in LIE Store building has negative assessment during the day and night. However, Rajabally building has positive assessment during the day and night.

CIMB Niaga is the fifth building, and the oldest store in the corridor of Kayutangan and the sixth building is Optic Surya. This building sells various kinds of glasses since the beginning the building was built until now.

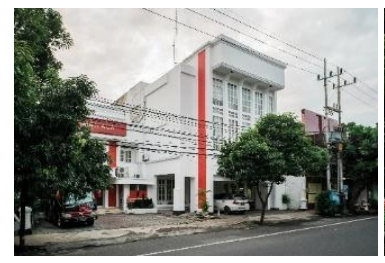

$5 a$

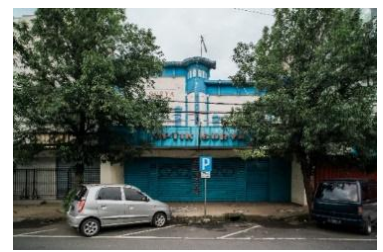

$6 a$

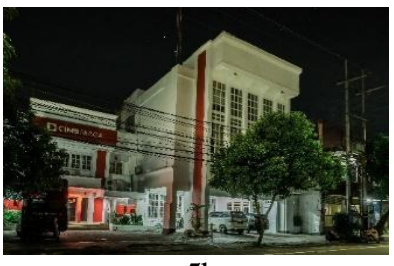

$5 \mathrm{~b}$

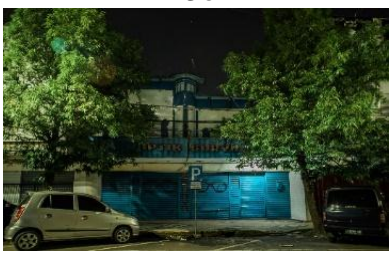

$6 \mathrm{~b}$
Fig. 4. 5a. LIE Store - Day (source: author); 5b. LIE StoreNight (source: author); 6a. Rajabally - Day (source: author); 6b. Rajabally - Night

The 100 respondents completed the measurement, and the results were compiled and tabulated (see Table 4). According to that table, the average value of each CIMB Niaga building ranged from 5 to 6 with 5.58 points during the day and 5.37 points during the night. While in Optic Surya building, that ranged from 4 to 5 with 4.61 points during the day and ranged from 3 to 4 with 3.52 points during the night. These results indicate that the assessment during the day in CIMB Niaga building has positive assessment during the day and night. However, Optic Surya building has a positive assessment during the day and has a negative assessment at night.

Namsin House is the seventh building and the oldest house in the corridor of Kayutangan. Namsin's house which was founded in 1900 without changing the style of the building until now. The eighth building is Riang Store. This building sells various kinds of clothes and many accessories since the beginning the building was built until now. 
Tabel 3. Average Score of LIE Store and Rajabally Building

\begin{tabular}{|c|c|c|c|c|c|c|c|c|c|c|c|c|c|c|c|c|c|}
\hline \multirow[t]{2}{*}{ No } & \multirow{2}{*}{$\begin{array}{l}\text { Aspect of Evalhation } \\
\text { (negative-posilive) }\end{array}$} & \multicolumn{2}{|c|}{$\begin{array}{c}\text { Average Soure of } \\
\text { LILStore }\end{array}$} & \multicolumn{6}{|c|}{ Graph of LIE Store } & \multicolumn{2}{|c|}{$\begin{array}{c}\text { Average Score of } \\
\text { Rajabaly Builing }\end{array}$} & \multicolumn{6}{|c|}{ Graph of Rajabaly Builing } \\
\hline & & Day & Night & 1 & 2 & 3 & 5 & 6 & 7 & Day & Night & 1 & 2 & 3 & 5 & 6 & 7 \\
\hline 1 & Building Mass (Closed-open) & 3.14 & 3.16 & & & & & & & 5,26 & 4,69 & & & & 99 & & \\
\hline 2 & Basic Form (Simple-complicated) & 4.62 & 426 & & & & & & & 5,02 & 4,58 & & & & & & \\
\hline 3 & Color Characteristics(Cold-warm) & 3.80 & 335 & & & & & & & 4,79 & 4,49 & & & & & & \\
\hline 4 & Saturation (Faded - bright) & 3.43 & $\mathbf{3 . 4 7}$ & & & & & & & 5,02 & 4,51 & & & & & & \\
\hline 5 & Brightness (Dark- light) & 3.81 & 326 & & & & & & & 5,07 & 4,42 & & & & & & \\
\hline 6 & Texture(Fim-soft) & 3.78 & 339 & & & & & & & 4,95 & 4,47 & & & & & & \\
\hline 7 & Ambince (Lonesome-lively) & 334 & 320 & & & & & & & 4,93 & 4,17 & & & & & & \\
\hline 8 & Lighting Effect(Ugly-beautiful) & 3.63 & 3.42 & & & & & & & 5,09 & 4,60 & & & & & & \\
\hline 9 & Harmony (Not suitable - suitable) & 3.86 & 3.48 & & & & & & & 5,03 & 4,56 & & & & & & \\
\hline 10 & Attractiveness (Common -interesting) & 431 & 356 & & & & & & & 5,23 & 4,68 & & & & & & \\
\hline 11 & Arts (Inartistic-artistic) & 3.83 & 351 & & & & & & & 5,07 & 4,74 & & & & & & \\
\hline 12 & Effect(Shabby-excellent) & 3.73 & 329 & & & & & & & 4,98 & 4,51 & & & & & & \\
\hline 13 & Lighting secunity (Unsafe-safety) & 420 & 3.55 & & & & & & & 5,16 & 4,26 & & & & & & \\
\hline \multirow[t]{3}{*}{14} & Visual Comfort(Unpleasant-pleasant) & 436 & 4.11 & & & b. & & & & 5,18 & 4,83 & & & & b & & \\
\hline & Grand Mean & 385 & 350 & & & & & & & 525 & 562 & & & & & & \\
\hline & $\begin{array}{l}x<4=\text { negative value, } \\
\mathbf{x}=\mathbf{4}=\text { positive value }\end{array}$ & & & & 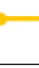 & : day & - & night & & & & & ? & day & $\bullet$ & night & \\
\hline
\end{tabular}

Notes: measurement scale of evaluation using a scale of 1 to 7 (from negative value to positive value)

Tabel 4. Average Score of CIMB Niaga and Optic Surya

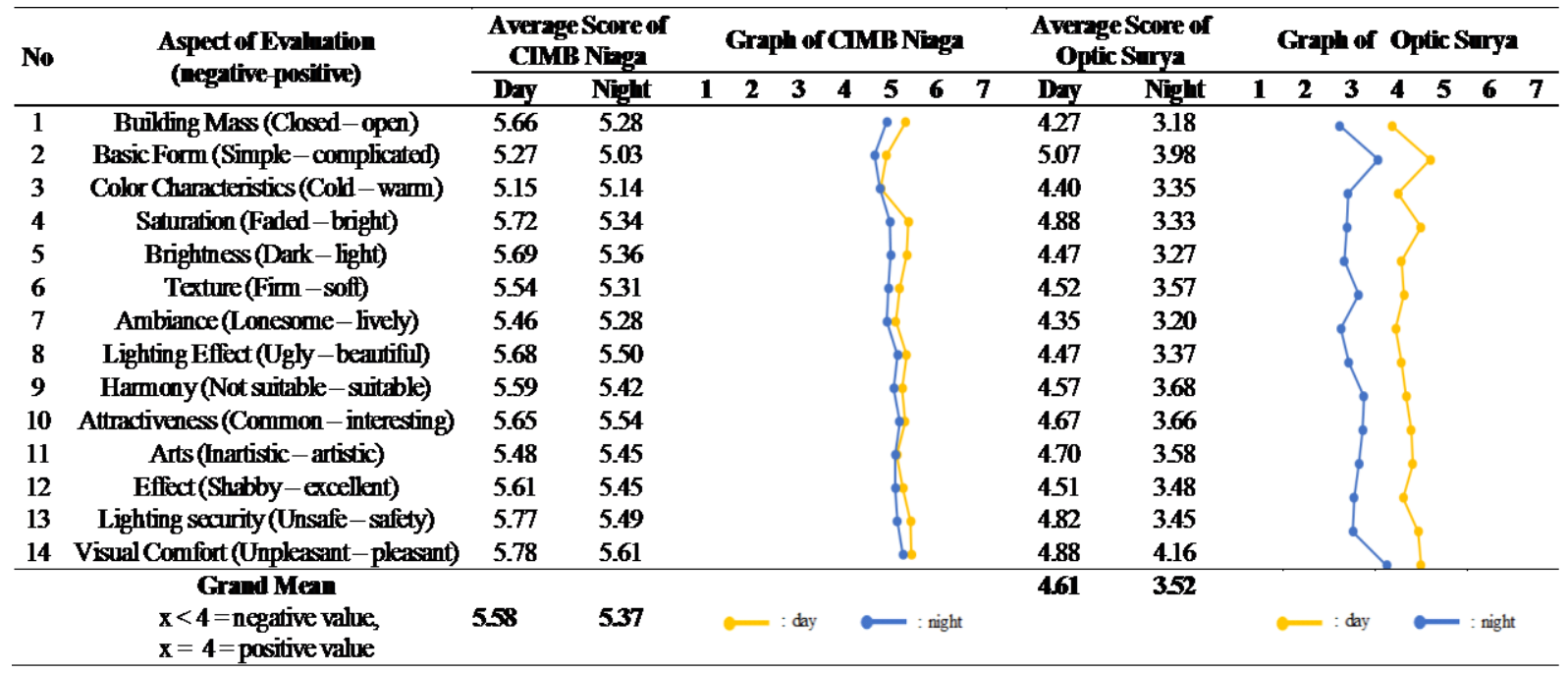

Notes: measurement scale of evaluation using a scale of 1 to 7 (from negative value to positive value)

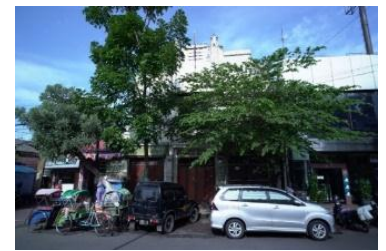

$7 \mathrm{a}$

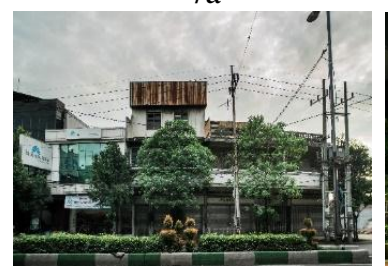

$8 \mathrm{a}$

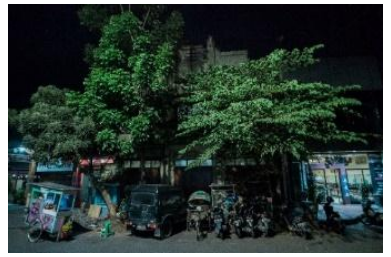

$7 \mathrm{~b}$

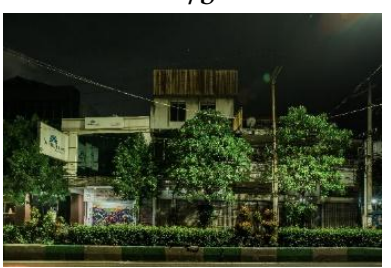

$8 \mathrm{~b}$
Fig. 5. 7a. Namsin House - Day (source: author); $7 \mathrm{~b}$. Namsin House - Night (source: author); 8a. Riang Store Day (source: author); 8b. Riang Store - Night
The 100 respondents completed the measurement, and the results were compiled and tabulated (see Table 5). According to that table, the average value of each Namsin House ranged from 4 to 5 with 4.12 points during the day and ranged from 2 to 3 with 2.88 points during the night. While in Riang Store building, that ranged from 4 to 5 with 4.21 points during the day and ranged from 3 to 4 with 3.31 points during the night. These results indicate that the assessment during the day in Namsin House and Riang Store building has a positive assessment during the day and have a negative assessment at night.

The ninth building is Kayutangan Church, which was founded in 1905. This church is a landmark of Malang City, especially with its towering towers with Neogothic style building. Last building is the OEN 
restaurant. "OEN Resaturant" is one among of the oldest family-owned restaurants that are still being run in 1936 until now in Malang City.

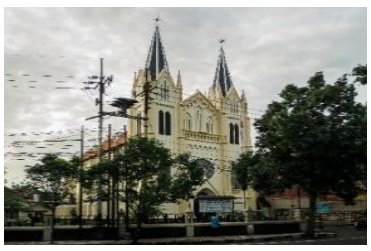

$9 \mathrm{a}$

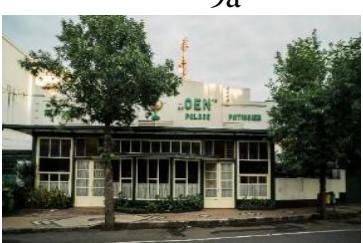

$10 \mathrm{a}$

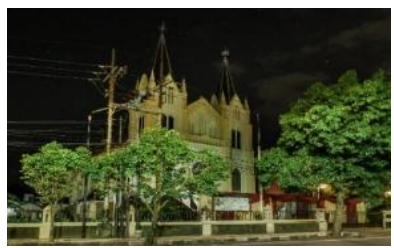

$9 \mathrm{~b}$

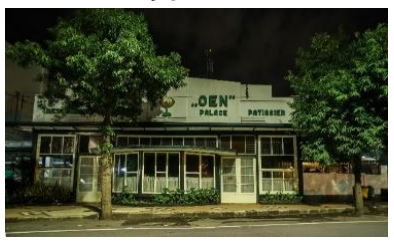

$10 \mathrm{~b}$
Fig. 6. 9a. Kayutangan Church - Day (source: author); 9b. Kayutangan Church - Night (source: author); 10a. OEN Day (source: author); 10b. OEN - Night
The 100 respondents completed the measurement, and the results were compiled and tabulated (see Table 5). According to that table, the average value of each Kayutangan Church ranged from 5 to 6 with 5.39 points during the day and 5.26 points during the night. While in OEN Restaurant that ranged from 5 to 6 with 5.69 points during the day and 5.66 points during the night. These results indicate that the assessment during the day in Kayutangan Church and OEN Restaurant have positive assessment during the day and night.

Based on Figure 6, it can be concluded that "LIE Store" is the building which visual building score during the day is lower than the grand mean. On the other hand, "LIE Store," "Optic Surya," "Riang Store" and "Rumah Namsin" are the buildings which visual building scores during the night are lower than the grand mean and make a negative assessment. This proves that people's assessment of visual quality at night with the same building is affected by the lighting.

Table 5. Average Score of Namsin House and Riang Store Building

\begin{tabular}{|c|c|c|c|c|c|c|c|c|c|c|c|c|c|c|c|c|}
\hline \multirow[t]{2}{*}{ No } & \multirow{2}{*}{$\begin{array}{l}\text { Aspect of Evaluntion } \\
\text { (negative posilive) }\end{array}$} & \multicolumn{2}{|c|}{$\begin{array}{c}\text { Average Score of } \\
\text { Namsin Honse }\end{array}$} & \multicolumn{5}{|c|}{ Graph of Namsin House } & \multicolumn{2}{|c|}{$\begin{array}{c}\text { Average Score of } \\
\text { Riang Store }\end{array}$} & \multicolumn{6}{|c|}{ Graph of Riang Stare } \\
\hline & & Day & Night & $\mathbf{1}$ & 2 & 4 & 5 & 7 & Day & Night & $\mathbf{1}$ & 2 & 4 & 5 & 6 & 7 \\
\hline 1 & Building Mass (Closed - open) & 3.62 & 2.51 & & & & & & 394 & 3.07 & & & & & & \\
\hline 2 & Basic Form (Simple-compFicated) & 4.59 & 331 & & & & & & 4.88 & 3.83 & & & & & & \\
\hline 3 & Color Characteristics(Cold-warm) & 3.73 & 2.55 & & & & & & 3.95 & 3.02 & & & & & & \\
\hline 4 & Saturation (Faded - bright) & 396 & 2.76 & & & & & & 3.84 & 299 & & & & & & \\
\hline 5 & Brightness (Dark - light) & 4.02 & 2.56 & & & & & & 4.16 & 3.05 & & & & & & \\
\hline 6 & Texture (Fimm-soft) & 421 & 2.87 & & & & & & 4.12 & 3.50 & & & & & & \\
\hline 7 & Ambiance (Lonesome-lively) & 3.79 & 2.60 & & & & & & 395 & 2.88 & & & & & & \\
\hline 8 & Lighting Effect (Ugly-beautiful) & 4.06 & 2.85 & & & & & & 4.04 & 339 & & & & & & \\
\hline 9 & Harmony (Not suitable-suitable) & 4.00 & 291 & & & & & & 4.25 & 3.42 & & & & & & \\
\hline 10 & Attractiveness (Common - interesting) & 430 & 299 & & & & & & 4.30 & 3.39 & & & & & & \\
\hline 11 & Arts (Inartistic-artistic) & 438 & 298 & & & & & & 4.35 & 3.44 & & & & & & \\
\hline 12 & Effect(Shabby-excellent) & 4.06 & 2.83 & & & & & & 4.01 & 3.08 & & & & & & \\
\hline 13 & Lighting secunity(Unsafe-safety) & 4.43 & 294 & & & & & & 4.45 & 331 & & & & & & \\
\hline \multirow[t]{3}{*}{14} & Visual Comfort (Unpleasant-pleasant) & 4.56 & 3.64 & & & d & & & 4.68 & 398 & & & & & & \\
\hline & Grand Mean & & & & & & & & 4.21 & 331 & & & & & & \\
\hline & $\begin{array}{l}x<4=\text { negative value } \\
x=4=\text { positive vahe }\end{array}$ & 4.12 & 2.88 & - & day & $\bullet$ & night & & & & 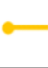 & day & & nig & & \\
\hline
\end{tabular}

Notes: measurement scale of evaluation using a scale of 1 to 7 (from negative value to positive value)

Table 6. Average Score of Kayutangan Church and OEN Restaurant

\begin{tabular}{|c|c|c|c|c|c|c|c|c|c|c|c|c|c|c|c|c|c|c|}
\hline \multirow[t]{2}{*}{ No } & \multirow{2}{*}{$\begin{array}{c}\text { Aspect of Evalnation } \\
\text { (negative positive) }\end{array}$} & \multicolumn{2}{|c|}{$\begin{array}{c}\text { Average Soure of } \\
\text { Ky tangan Chunch }\end{array}$} & \multicolumn{6}{|c|}{$\begin{array}{c}\text { Graph of Kayetangan } \\
\text { Chninch }\end{array}$} & \multicolumn{2}{|c|}{$\begin{array}{l}\text { Average Score of } \\
\text { OEN Restairant }\end{array}$} & \multicolumn{7}{|c|}{ Graph of OWN Restanrant } \\
\hline & & Day & Night & $\mathbf{1}$ & 2 & 3 & 45 & 6 & 7 & Day & Night & $\mathbf{1}$ & 2 & 3 & 4 & 5 & 6 & 7 \\
\hline 1 & Building Mass (Closed - open) & 5.16 & 5.08 & & & & & & & 6.01 & 5.62 & & & & & 9 & & \\
\hline 2 & Basic Form (Simple-complicated) & 420 & 493 & & & & & & & 5.62 & 5.73 & & & & & & & \\
\hline 3 & Color Characteristics (Cold-warm) & 530 & 498 & & & & & & & 5.42 & 5.41 & & & & & & & \\
\hline 4 & Saturation (Faded - bright) & 5.48 & 525 & & & & & & & 5.61 & 568 & & & & & & & \\
\hline 5 & Brightness (Dark - light) & 5.48 & 5.13 & & & & & & & 5.69 & 5.41 & & & & & $\oint$ & & \\
\hline 6 & Texture (Fim - soft) & 5.02 & 5.10 & & & & & & & 5.44 & 5.51 & & & & & & & \\
\hline 7 & Ambiance (Lonesome-lively) & 523 & 5.04 & & & & & & & 5.64 & 5.51 & & & & & $\phi$ & & \\
\hline 8 & Lighting Effect(Ugly-beautiful) & 557 & 538 & & & & & & & 5.74 & 5.69 & & & & & & & \\
\hline 9 & Harmony (Not suitable - suitable) & 5.53 & 528 & & & & & & & 5.73 & 5.64 & & & & & & & \\
\hline 10 & Attractiveness (Common - interesting) & 5.75 & 5.43 & & & & & & & 5.92 & 5.84 & & & & & 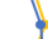 & & \\
\hline 11 & Arts (Inartistic - artistic) & 5.79 & 5.84 & & & & & & & 5.69 & 5.87 & & & & & t & & \\
\hline 12 & Effect(Shabby-excellent) & 5.64 & 533 & & & & & & & 5.59 & 5.69 & & & & & $\phi$ & & \\
\hline 13 & Lighting security (Unsafe-safety) & 560 & 535 & & & & & & & 5.78 & 5.82 & & & & & & & \\
\hline \multirow[t]{3}{*}{14} & Visual Comfort(Unpleasant-pleasant) & 567 & 5.51 & & & & . & & & 5.82 & 5.85 & & & & & & & \\
\hline & Grand Mean & & & & & & & & & 5.69 & 566 & & & & & & & \\
\hline & $\begin{array}{l}x<4=\text { negative value } \\
x=4=\text { positive value }\end{array}$ & 539 & 5226 & & 6 & : day & 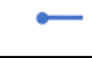 & night & & & & & 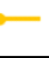 & : day & & 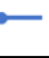 & night & \\
\hline
\end{tabular}

Notes: measurement scale of evaluation using a scale of 1 to 7 (from negative value to positive value) 


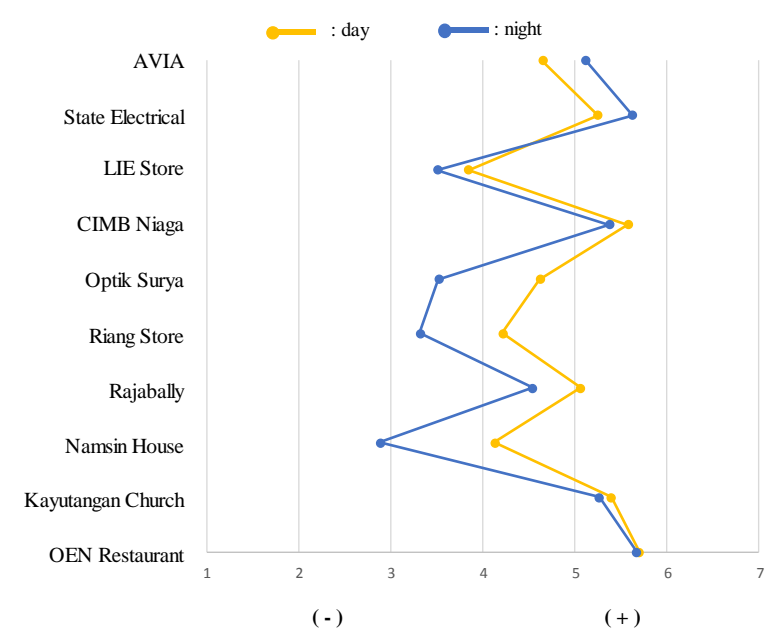

Fig. 7. Average Scores (Mean) of 10 Buildings in Kayutangan
Based on 14 aspects that have been analyzed in each building, it is necessary to know the variables that affect the visual quality of buildings by conducting multiple linear regression analysis. The results of multiple linear regression analysis will be displayed are analyzes during the day and night.

Tabel 8 (MS) provides the $\mathrm{R}$ and $\mathrm{R} 2$ values during the day. The $\mathrm{R}$ value represents the simple correlation and is 0.876 (the "R" Column), which indicates a high degree of correlation during the day. The R Square value (the "R Square" column) indicates how much of the total variation in the dependent variable can be explained by the independent variable. In this case, $76.7 \%$ can be explained at day time, which is very large. At Night, The R value represents the simple correlation and is 0.919 (the "R" Column),

Table 7. Descriptive Statistic of the Building during day and night in Kayutangan Malang.

\begin{tabular}{|c|c|c|c|c|c|c|}
\hline \multicolumn{7}{|c|}{ Descriptive Statistics } \\
\hline \multirow{2}{*}{ Aspect of Evaluation } & \multicolumn{3}{|c|}{ Day } & \multicolumn{3}{|c|}{ Night } \\
\hline & Mean & Std. Deviation & $\mathbf{N}$ & Mean & Std. Deviation & $\mathbf{N}$ \\
\hline Visual Quality Building & 4.91 & 1.695 & 1000 & 4.55 & 1.851 & 1000 \\
\hline Building Mass (Closed - open) & 4.68 & 1.895 & 1000 & 4.30 & 1.938 & 1000 \\
\hline Basic Form (Simple - complicated) & 4.95 & 1.629 & 1000 & 4.64 & 1.741 & 1000 \\
\hline Color Characteristics (Cold - warm) & 4.57 & 1.699 & 1000 & 4.29 & 1.874 & 1000 \\
\hline Saturation (Faded - bright) & 4.66 & 1.700 & 1000 & 4.39 & 1.812 & 1000 \\
\hline Brightness (Dark - light) & 4.88 & 1.614 & 1000 & 4.32 & 1.819 & 1000 \\
\hline Texture (Firm - soft) & 4.71 & 1.546 & 1000 & 4.43 & 1.753 & 1000 \\
\hline Ambiance (Lonesome - lively) & 4.55 & 1.733 & 1000 & 4.23 & 1.906 & 1000 \\
\hline Lighting Effect (Ugly - beautiful) & 4.80 & 1.592 & 1000 & 4.48 & 1.751 & 1000 \\
\hline Harmony (Not suitable - suitable) & 4.85 & 1.573 & 1000 & 4.51 & 1.742 & 1000 \\
\hline Attractiveness (Common - interesting) & 5.07 & 1.687 & 1000 & 4.60 & 1.834 & 1000 \\
\hline Arts (Inartistic - artistic) & 4.97 & 1.619 & 1000 & 4.64 & 1.827 & 1000 \\
\hline Effect (Shabby - excellent) & 4.80 & 1.522 & 1000 & 4.45 & 1.762 & 1000 \\
\hline Lighting security (Unsafe - safety) & 5.07 & 1.520 & 1000 & 4.51 & 1.774 & 1000 \\
\hline Visual Comfort (Unpleasant - pleasant) & 5.14 & 1.400 & 1000 & 4.90 & 1.536 & 1000 \\
\hline
\end{tabular}

Predictors : (Constant), Visual Comfort, Structure, Color Characteristics, Attractiveness, Building Mass, Texture, Arts, Brightness, Ambiance, Harmony, Lighting security, Saturation, Effect, Lighting Effect

Dependent Variable: Visual Quality Building

Table 8. Model Summary of the Building during day and night in Kayutangan, Malang City

\begin{tabular}{cccccc}
\multicolumn{7}{c}{ Model Summary $^{\mathbf{b}}$} \\
\hline Time & Model & R & R Square & Adjusted R Square & Std. Error of the Estimate \\
\hline Day & 1 & $.876^{\mathrm{a}}$ & .767 & .763 & .825 \\
Night & 1 & $.919^{\mathrm{a}}$ & .845 & .842 & .735 \\
\hline
\end{tabular}

Predictors : (Constant), Visual Comfort, Structure, Color Characteristics, Attractiveness, Building Mass, Texture, Arts, Brightness, Ambiance, Harmony, Lighting security, Saturation, Effect, Lighting Effect

Dependent Variable: Visual Quality Building

Table 9. ANOVA test of the Building during day and night in Kayutangan, Malang City

\begin{tabular}{|c|c|c|c|c|c|c|c|c|c|c|}
\hline \multicolumn{11}{|c|}{ ANOVA $^{\mathrm{a}}$} \\
\hline & \multicolumn{5}{|c|}{ Day } & \multicolumn{5}{|c|}{ Night } \\
\hline & Sum of Squares & df & Mean Square & $\mathbf{F}$ & Sig. & Sum of Squares & df & Mean Square & $\mathbf{F}$ & Sig. \\
\hline Regression & 2201.241 & 14 & 157.232 & 231.180 & .000 & 2889.436 & 14 & 206.388 & 382.382 & .000 \\
\hline Residual & 669.923 & 985 & .680 & & & 531.648 & 985 & .540 & & \\
\hline Total & 2871.164 & 999 & & & & 3421.084 & 999 & & & \\
\hline
\end{tabular}

Predictors: (Constant), Visual Comfort, Structure, Color Characteristics, Attractiveness, Building Mass, Texture, Arts, Brightness, Ambiance, Harmony, Lighting security, Saturation, Effect, Lighting Effect

Dependent Variable: Visual Quality Building 
which indicates a very high degree of correlation during the day. The R Square value (the "R Square" column) indicates how much of the total variation in the dependent variable explained by the independent variable. In this case, $84.5 \%$ can be explained at night time, which is very large.

Table 10 proves that variables have significant influence on Visual Quality Building during the day are building mass, brightness, harmony, attractiveness, effect and arts. The most influential variable on the visual quality of buildings from the highest values are Arts $(\mathrm{B}=.294)$, Harmony $(\mathrm{B}=.233)$, Attractiveness $(\mathrm{B}=.190)$, Brightness $(\mathrm{B}=.140)$, Building Mass $(\mathrm{B}=.084)$, and Effect $(\mathrm{B}=.079)$. Different from the night, variables that have significant influence on People Assessment during at night are Basic Form, Color Characteristic, Brightness, Lighting Effect, Harmony, Attractiveness, Arts, and Lighting Security. The most influential variable on the visual quality of buildings from the highest values are Arts $(\mathrm{B}=.345)$, Attractiveness $(\mathrm{B}=.275)$, Lighting Effect $(\mathrm{B}=.160)$, Brightness $(\mathrm{B}=.095)$, Color Characteristic $(\mathrm{B}=)$, Lighting Security $(B=)$, Harmony $(B=)$, dan Basic Form $(\mathrm{B}=)$.

Building mass variable have explained perception about hollow or solid on building. In a study, Askari and Dola (2009) and have proved public's assessment of building facades are based on form, information about identity and background of the building, or knowledge, function of the building, and familiarity. It proves how important is building mass. The same thing is also mentioned by Shirvani (1985), one of elements of visual characters is massing. Different from night, daylighting is more evenly distributed to building facade.

Basic Form variable have explained perception about simple or complicated on building form. According to Shirvani (1985), forming elements of visual characters are basic forms and massing. Shirvani's opinion is also a union with the building mass. At night, basic form with night lighting.

Color characteristic variable have explained perception about cold or warm on building. According to Antariksa (2017) and Ashfa (2007) conclude color is one of the visual characters of a building. Similar opinion is mentioned by Maust (2013), color is may the most easily seen and recognized physical aspect in our surroundings and provide the significant impact of architectural color on the overall perception of environment. The result of the color is the main and fundamental thing in a visual identity of buildings.

Brightness variable have explained perception about dark or bright color tones on building. (Fauziah,
Antariksa et al., 2012) proved that one of influence visual factor of facade quality post-modern colonial building are Color Dimension (texture, material, ornament, color, brightness). (Utaberta et al., 2012) have been stated different opinion. They mentioned brightness having strong correlation with facade and having lowest mean which confirmed that brightness of facade color has negative assessment on the quality of city image in building facades. The aesthetic aspects are needed to identifying the and determining the required art effects which are influenced by the building form as well as by the building surface color and quality and the brightness of the neighborhood environment and surrounding (Górczewska \& Mroczkowska, 2015). This proves that the brightness caused by the environment affects the appearance of the building and other aspects. As one of the influential variables, Brightness of buildings is very influential during the day and night. Brightness from natural and artificial lighting at night giving different brightness. Natural and artificial lighting have made the atmosphere of the building day and night look different.

Lighting effect variable have explained perception about ugly or beautiful on façade building. (Zakaria and Bahauddin, 2015) explained that the effects of lighting on buildings are improving health, enhance performance, and enhance the aesthetic values of buildings. The effect of lighting is regarded as increasingly important in presenting a building as a positive thing. Meanwhile, Manurung (2008) stated night lighting designs that should be able to improve the visual quality of buildings and horrible lighting design approaches can reduce the visual quality of the building. Lighting effect had positive and negative impact on buildings and its surroundings.

Harmony variable have explained perception about suitable or not suitable on façade building with day or night lighting. If the harmony score increases, then people assessment will be higher. The correlation between architectural geometry and design starts with the notion of harmony as the principle for all sciences and creations. The analysis of the antique comprehension of harmony showed the geometrical root and the superior idea of this concept for design and sciences (Leopold, 2006). Architectural aesthetics is a coherent system of criteria which are formal and symbolic at the same time and the formal things is concerned with questions of proportion, harmony and contrast. (Sotoudeh and Abdullah, 2012). It can be concluded that harmonics is one aspect that influences the aesthetics of the building against people's perceptions. 
Table 10. Multiple Linear Regression of Building during day and night on Kayutangan

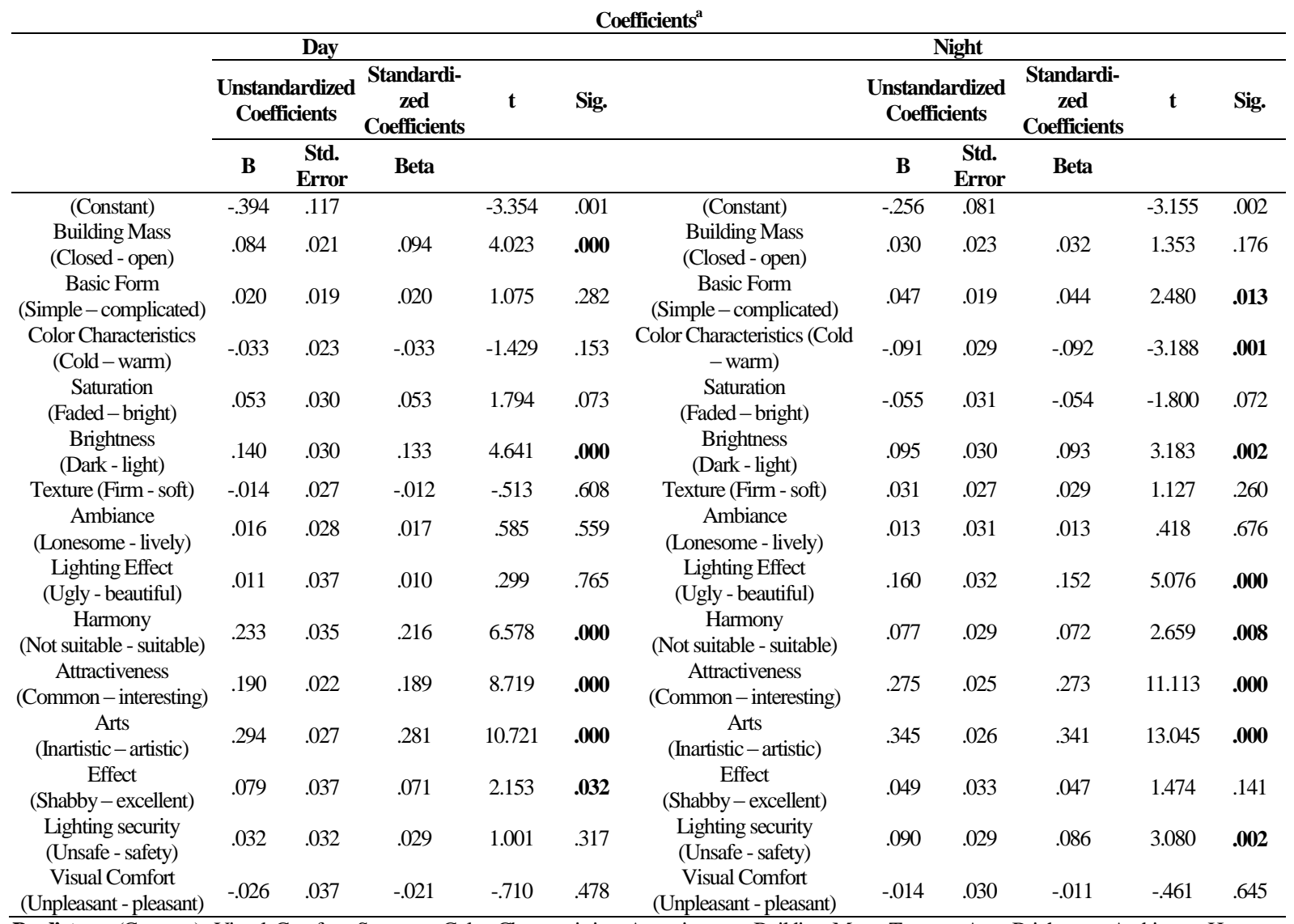

Predictors: (Constant), Visual Comfort, Structure, Color Characteristics, Attractiveness, Building Mass, Texture, Arts, Brightness, Ambiance, Harmony, Lighting security, Saturation, Effect, Lighting Effect

Dependent Variable: Visual Quality Building

Attractiveness variable have explained perception about common or interesting on façade building with day or night lighting. (Adiwibowo and Widodo et al., 2015) mentions positive perceptions shown by people assessment and the attraction of the exterior of the building can be considered as main points in building. Attractiveness is one aspect that is shaped by the dominant form around, the abstraction that does not dominate, and the formation of a building to attract the attention of observers or visitors to the area (Wirawan 2014). Other researches stated that the attraction of the facade at night is supported by lighting on the facade that uses illumination technology (Sulistyandari et al., 2017). This proves that the attraction of buildings is influenced by lighting because that shows the detailed side of a building different from other buildings.

Arts variable have explained perception about inartistic or artistic on façade building. Arts of Architecture is considered as art knowledge, namely the art of building. Art of building architecture is considered as a 'taste' which is based on feeling as the source of the idea (Sumalyo, 2005). Light art has been used for historic buildings to express cultural, and visual importance (Zakaria and Bahauddin, 2015). The Art of building can be displayed through with good lighting and make the art details can be seen easily.

Effect variable have explained perception about shabby or excellent. The meaning of effect is the impact of lighting on the environment around building. (Manurung, 2015) proved that visual perception during the day shown that visual information obtained from buildings is complete enough so that architectural elements can be enjoyed properly. The result the lighting in a building should not make the surrounding environment worse like glare and negative impression for buildings and pedestrians.

Lighting Security variable have explained perception about unsafe or safety around building between building and visitors. (Peña-García et al., 2015) and (Cafuta, 2014) explains that lighting design should be able to provide positive perceptions such as feeling comfortable and safe outside buildings, pedestrians and reducing criminal acts. Similar opinion is mentioned by Pease (1999) suggested that general increase of lighting will reducing criminal. Other opinions from Raynham (2007) reported that good 
lighting can prevent crime by increasing the chance of informal surveillance. This proves that the importance of lighting provides security perceptions of crime outside the building and surroundings.

The conclusion of the visual quality assessment of buildings during the day and night shows that there were 4 buildings which their visual quality got low scores compared to those daylight buildings. Those buildings are Namsin House, Riang Store, Lie Store, and Optic Surya. The assessment was supported by public perceptions, and it had proven that visual quality at night was influenced by eight aspects (Basic Form, Color Characteristic, Brightness, Lighting Effect, Harmony, Attractiveness, Arts, and Lighting Security). It's different from visual quality during day. Visual quality at the day was influenced by six aspects (building mass, brightness, harmony attractiveness, effect and arts). It can be concluded Brightness, Harmony, Attractiveness and arts are the most influential aspects of visual quality between day and night in buildings.

\section{CONCLUSION}

Public opinion about the visual quality of these buildings in the day or night describes the influence of lighting towards building exterior. According to the respondents, these buildings have a higher visual quality score during the day than during the night.

There are no different on visual quality of the buildings regards of building massing, the value of art, and security lighting between the day and night. The difference of people perception in the visual aspect of lighting effects.

From 4 of 10 the buildings ("LIE Store," "Riang Store," "Rumah Namsin," and "Optic Surya," have a low visual quality based on people's assessment during the night due to artificial lighting. These buildings are the public's least favorite buildings in the area. "LIE Store" has low visual quality during the day and night score. Besides lighting quality, several other indicators, affect the visual quality. During the day, the most influential aspects of visual quality are Building Mass, Brightness, Harmony, Attractiveness, Effect and Arts. At night, the most influential aspects of visual quality are Basic Form, Color Characteristic, Brightness, Lighting Effect, Harmony, Attractiveness, Arts, and Lighting Security.

Future researchers are expected to conduct studies discussing night lighting, for example how much influence placement of night lighting has on visual quality of the architectural building or which types of artificial lighting tones that become the most suitable tone for the architectural building.

\section{REFERENCES}

Adiwibowo, R.S., Widodo, P., and Santosa, I. (2015). Correlations Between Public Appreciation of Historical Building and Intention to Visit Heritage Building Reused as Retail Store. Procedia Social and Behavioral Sciences. (184): 357-364.

Anggriani, N. (2007). Meningkatkan Citra Visual Masa Lalu Kota Melalui Pencahayaan. Rekayasa Perencanaan. 3(3).

Antariksa (2017). Teori \& Metode Pelestarian Arsitektur \& Lingkungan Binaan. Yogyakarta, Cahaya Atma Pustaka.

Ashfa (2007). Upaya Untuk Mengembalikan Sense of Place di Pedestrian Mall Koridor Jalan TGK. Chikpantekulu Kota Banda Aceh Melalui Rehabilitasi Bangunan Pertokoan Lama. Teknik Sipil VI. 1: 69-76.

Askari, A.H., and Dola, K.B. (2009). Influence of Building Façade Visual Elements on Its Historical Image: Case of Kuala Lumpur City, Malaysia. Journal of Design and Built Environment 5: 49-59.

Cafuta, M.R. (2014). "Visual Perception and Evaluation of Artificial Night Light in Urban Open Area." Informatol. 47(4): 257-263.

Ernawati, J., and Moore, G.T. (2014). Tourist' and Residents' Impressions of a Heritage Tourism Site The Case of Kampong Taman Sari, Indonesia. International Journal of Architectural Research. Archnet-IJAR. 8(3).

Fauziah, N., Antariksa and Ernawati, J. (2012). Kualitas Visual Fasade Bangunan Modern Pasca Kolonial di Jalan Kayutangan Malang. Jurnal RUAS. 10(2).

Flynn, J. (1973). Journal of Illuminating Engineering Society.

Gokhale, V.A. (2013). People's Perception of Urban Lighting in Public Space. CCA Research Cell. Journal of Architecture.

Hafiz, D. (2015). Daylighting, Space, And Architecture: A Literature Review. Enquiry. 12(1): 1-8.

Jennath, K.A., and Nidhish, P.J. (2016). Aesthetic judgement and visual impact of architectural forms: a study of library buildings. Procedia Technology. 24: 1808-1818.

Karisztia, A.D., Pangarsa, G.W., and Antariksa (2008). Tipologi Façade Rumah Tinggal Kolonial Belanda Di Kayutangan - Malang. Arsitektur e-Journal. 1(2).

Leopold, C. (2006). Geometry Concepts in Architectural Design. $12^{\text {th }}$ International Conference on Geometry AND Graphics. T35: 1-9. 
Liu, Y., Kang, J., Zhang, Y., Wang, D., and Mao, L. (2015). Visual Comfort Is Affected By Urban Colorscape Tones In Hazy Weather. Frontiers of Architectural Research. 5: 453-465.

Lynch, K. (1969). Site Planning. Chicago, University of Chicago Press.

Mahmoudi, M., and Ahmad, F. (2015). Determinants of livable streets in Malaysia: A study of physical attributes of two streets in Kuala Lumpur. Urban Design International. 20: 158174.

Manurung, P. (2008). Kualitas Pencahayaan Pada Bangunan Bersejarah. .DIMENSI Teknik Arsitektur. 36(1): 28-34.

Manurung, P. (2015). Pendekatan Desain Pencahayaan Fasade Bangunan Bersejarah. Simposium Nasional RAPI XIV FT UMS: A8 - A12.

Maust, E.J. (2013). Placing Color: Architectural Color \& Facade Improvement Programs in Commercial Corridor Revitalization in Philadelphia, University of Pennsylvania.

Pease, K. (1999). A review of street lighting evaluations: Crime reduction effects. Surveillance of Public Space: CCTV, Street Lighting and Crime Prevention. Crime Prevention Studies. (10): 4776.

Peña-García, A., Hurtado, A., and Aguilar-Luzón, M.C. (2015). Impact of public lighting on pedestrians' perception of safety and well-being. 78: 142-148.

Perovic, S., and Folic, N.K. (2012). Visual Perception of Public Open Spaces in Niksic. Procedia Social and Behavioral Sciences. 68: 921-933.

Rankel, S. (2014). Future Lighting And The Appearance Of Cities At Night: A Case Study. Urbani izziv._25(1).

Raynham, P. (2007). Public Lighting in Cities. International Conference Illuminat 2007. Cluj Napoca, Rumania.

Sachari, A. (2007). Budaya Visual Indonesia: membaca makna perkembangan gaya visual karya desain di Indonesia abad ke-20. Jakarta, Erlangga.

Sanoff, H. (1991). Visual Research Methods in Design. Van Nostrand Reinhold Company Inc., New York

Santosa, H., Ikaruga, S., and Kobayashi, T. (2013). Visual Evaluation of Urban Commercial Streetscape Through Building Owners Judgment:
Case Study in Malang city, Indonesia. Journal of Architecture and Planning. 78(691): 1995-2005.

Santosa, H., Ikaruga, S., and Kobayashi, T. (2014). "Development of Landscape Support System Using Interactive 3D Visualization." Journal of Architecture and Planning. 79(706): 1995-2005.

Shirvani, H. (1985). Urban Design Process. New York, Van Nostrand Reinhold.

Sotoudeh, H., and Abdullah, W.M.Z.W. (2012). Affected Variables on Successful Infill Design in Urban Historic Context. Arts and Design Studies. 3: 7-12.

Sulistyandari, U., Nugroho, A.M., and Sufianto, H. (2017). Fasad Hi-Tech Mall Surabaya dengan Konsep Fasad Atraktif. Jurnal Universitas Brawijaya: Jurnal Mahasiswa Jurusan Arsitektur. $5(1)$.

Sumalyo, Y. (2005). Arsitektur Modern Akhir Abad XIX dan abad XX. Yogyakarta, Gajah Mada University Press.

Utaberta, N., Jalali, A., Johar, S., Surat, M. and CheAni, A.I. (2012). Building Facade Study in Lahijan City, Iran: The Impact of Facade's Visual Elements on Historical Image. World Academy of Science, Engineering and Technology International Journal of Humanities and Social Sciences. 6(7): 1839 - 1844.

Widiantoro, B., Robert, R., and Widjaja, A.N. (2015). Pengaruh Pencahayaan pada Bangunan di Malam Hari terhadap Pembentukan Persepsi Pengguna Jalan di Kawasan Retail Kota Semarang. Prosiding Temu Ilmiah IPLBI 2015: 23-30.

Wirawan, I.M.Y. (2014). Penerapan Konsep Arsitektur Infill pada Bangunan Museum dalam Kawasan Heritage di Banjarmasin Studi Kasus : Memorial Park Soekarno, Blitar dan Museum Nasional, Jakarta. E-Journal Graduate Unpar. l(2): 213-220.

Zakaria, S.A., and Bahauddin, A. (2015). Light Art for Historical Buildings: A Case Study of the Heritage Buildings in George Town, Penang Island. Procedia - Social and Behavioral Sciences. (184): 345 - 350

Zhang, M., Nakashima, Y., and Takamatsu, M. (2010). Research on Illumination of Historical Buildings by the Color Temperature. IJCSNS International Journal of Computer Science and Network Security. 10(8). 